\title{
DIGITAL ECONOMY FEATURES IN THE FIELD OF STATE ELECTRONIC SERVICES IN THE RUSSIAN FEDERATION
}

\author{
PAVLOVICH Vyacheslav Vasiliev', BATRAZOVNA Valentina Dzobelova ${ }^{2}$, \\ SHAMSUDINOVNA Deschi Musostova ${ }^{3}$, VIKTOROVNA Anna Zemtsova ${ }^{4}$, \\ SEMENOVNA Natiya Shitukhina ${ }^{5}$
}

\author{
${ }^{1}$ FSBEI HE "Kuban State Agrarian University named after I.T. Trubilin” (RUSSIAN) \\ ${ }^{2}$ North-Ossetian State University named after K.L. Khetagurova (RUSSIAN) \\ ${ }^{3}$ FSBEI HE "Chechen State University" (RUSSIAN) \\ ${ }^{4}$ Belorechensk Branch of FSBEI HE "Adygeya State University” (RUSSIAN) \\ ${ }^{5}$ Belorechensk Branch of FSBEI HE "Adygea State University" (RUSSIAN)
}

\begin{abstract}
The sharp increase in information and communication technologies, and, above all, the Internet, is a characteristic feature of globalization; it determines the progress of the world community to a new type of economy, which is increasingly called the digital (information) economy. The common features of the digital economy include a shift in most of the social, including economic, interaction into electronic space; promotion of distance work statuses and information transfer types; replacing people with robots in labor-intensive and hazardous industries; using electronic money, etc.

In today's realities, information itself, undoubtedly, serves as a key strategic resource, the extent of which involvement can be compared with the use of traditional resources. As a result, access to information bases can be considered as an important factor in social, economic and even political development.

In the conditions of constant transformation and increasing competition, we have to constantly look for new ideas and forms of organization of the economy and society in order to ensure sustainable development and effective functioning with a radical change in communication forms. It should also be noted that in the last decade there has been a significant modernization of previous ideas, attitudes, stereotypes and models of interaction between government structures, business structures, and civil society.

Experts note the activation of the state in establishing economic relations and interaction between all interested participants by structuring the system of socio-economic relations and giving this system integrity and vitality. Among the priority areas of informatization processes there is the building of a system of electronic public services, through which the state provides a range of information services (for private applications, during state (municipal) procurements, etc.).

Another independent and no less important problem is the need to study various aspects of standardization in the field of the digital economy in the Russian Federation. This is due to the peculiarities of the development of economic and technological components in the digital economy in Russia. Indeed, as many experts note, the fruitful theoretical development and the rich practice of standardizing complex socio-ecological-economic systems should allow us to develop a flexible regulatory mechanism by which we can provide the necessary balance between imperative state regulation and many dispositive contractual relations of participants in the digital transformation of the economy. And today it must be noted that only 29 standards of the more than 5300 national standardization system documents (GOST, GOST $\mathrm{R})$ meet the requirements of the digital economy.
\end{abstract}


The relevance of this paper is associated with the fact that the development of standardization of information and communication technologies (ICT) bears an enormous potential, which requires a scientific understanding of the prospects and consequences in socio-economic life.

Keywords: world economy, globalization, digital economy, state electronic services, information society

JEL: $O 10$

UDC:330.341.1(470) 007:004]:33

COBISS.SR-ID: 18169609

\section{Introduction}

In the course of our study, we decided to focus on the problems of standardization of the digital economy, due to the inadequate development level of the Russian file of standards for digital transformation of the economy, as well as the urgent need for methodological provisions for analysis and diagnostics to ensure the effectiveness of the implementation of the national project "Digital Economy".

To clarify the standards for selection of criteria related to the digital economy, on the whole array of the File of standards, we have chosen the determination of the "digital economy" concept given in the Presidential Decree dated 09.05.2017 "On the Strategy for Information Society Development in the Russian Federation for the period of 2017-2030". In accordance with the definition given in it, we mean by the digital economy "the economic activity in which the key factor in production is digital data, the processing of large volumes and the use of analysis results of which in comparison with traditional forms of management can significantly increase the efficiency of various types of production, technologies, equipment, storage, sale, delivery of goods and services".

This document also strictly states that there is the standardization system developed by various standardization technical committees, including FSUE Standartinform among the main areas of development of domestic information and communication technologies.

However, experts note that the majority of documents $(97.5 \%)$ of national and interstate standardization do not correspond to the digital economy documents. However, this provision in October 2019 was also admitted by the Chairman of the Government of the Russian Federation.

In this regard, experts note the desire to develop their own standards in almost all areas of the digital economy.

Others propose to adapt actively promising foreign standards to Russian reality, as well as to emphasize the harmonization of GOST R standards with international ones. [3], [13]

We believe that it is also necessary to focus on the accelerated development of GOST R, the more that Russia already has a disruptive technology that will certainly require developing their own appropriate standards.

It is clear that all this is associated with significant material and human resources, as well as with time expenditures. It should also be noted that in accordance with Russian legislation, the state budget does not provide for full coverage of all standardization costs.

Concerning digital economy, one of the most important issues of improving Federal Law "On standardization in the Russian Federation" and other basic standards, is the need to establish an effective relation between standards and intellectual property of innovative companies that can increase the maximum positive effects of standardization on innovation, and to neutralize the negative effects. 


\section{Research Methodology}

The main provisions of the institutional theory, developments of leading foreign and Russian scientists in the field of standardization of the digital economy, informatization and electronization of public services were the methodological basis of this study.

The study used systemic and multidisciplinary approaches to the processes under study.

Also, we used such general scientific methods as analysis and synthesis, deduction and induction, comparison, and generalization.

\section{Research Results}

It should be noted that, in general, there are 2 approaches in the world practice of supporting the development of information and communication technologies:

- The US and EU approaches;

- The approach inherent in the countries of the Far Eastern region.

Naturally, these different models of the formation and development of the information society have different political and economic results.

A characteristic feature of the Western model (USA, EU) is that they are open to innovation, but this is fraught with many risks, including the threat of loss of strength, finances and time.

The second model adopted in the Far East is characterized by the concentration of power, finance and invest time on selected investment projects. Such an approach (according to experts) seems more effective.

In our work, we proceed from the fact that the development of information society should be accompanied by an increase in the level and quality of life of the entire population. Indeed, global informatization is focused on the elimination of obstacles and inequalities in developing countries in the process of transforming humanity towards the global information community.

The main value of the information society in modern realities is information. Therefore, it can be argued that the prosperous development of the information society requires a clear institutional settlement related to the protection of a personal property, an intellectual property in the field of collection, processing and dissemination of digital information, the protection of technological information, patents, etc. [1], [5], [14].

In recent years, there has been a large increase in the knowledge resources accumulated in global information systems. It is no secret that the desire for a new public life is global in its nature.

Apparently for this reason, almost all countries of the world economy are taking part in the implementation of informatization processes.

At the turn of the $21^{\text {st }}$ century, the basic principles of the idea of creating "electronic" Russia were formulated in the Russian Federation.

Undoubtedly, one of the effective levers to eliminate Russia's serious economic lag from advanced countries is to intensify the development of the high-tech information and telecommunications sector.

It is no accident that the administrative reform in the Russian Federation and its informatization has been associated with the start of the special program "Electronic Russia" (2002-2010).

In February 2008, in accordance with the Presidential order No. 212, the Russian Federation began to implement the information society. For this, the "Strategy for the Information Society Development in the Russian Federation" was developed and implemented. 
In this strategy, the goal, objectives, principles and main directions of state policy in the field of the development of information and communication technologies and their active application in science, education and culture were specified in detail to advance the Russian Federation along the path of building and sustainable development of the information society [6]. This strategy was aimed at improving the quality of life of the population, ensuring the national economy competitiveness for Russia, developing the socio-political, cultural, economic and spiritual spheres of society, improving the public administration system based on the active use of the capabilities of information and communication technologies.

It was planned that by 2015 a set of control values for the following indicators would be reached without fail:

- The Russian Federation should, in accordance with the UN international ratings for the development of the information society, enter the first "twenty" of the leading powers of the world;

- At the same time, the Russian Federation should enter the top ten according to the Russian infrastructure accessibility level of information and communication technologies for the subjects of the information sphere;

- To bring the degree of accessibility for the population of information and communication technology services to $100 \%$;

- To reduce differences between regions of the Russian Federation with regard to the main indicators of information development up to 2 times;

- To bring the share of research and development in the field of information and communication technologies in research institutes and research-and-development activity to $30 \%$;

- The share of library collections that will be converted into electronic form should be brought to $50 \%$, and for library catalogs - to $100 \%$, etc.

We need to state that up to 2015 even a third of the planned indicators has not been achieved.

It seems that Russia should be more widely represented in international cooperation concerning the problems of sustainability of the information society development.

In 2011, the new state program of the Russian Federation, "Information Society (20112020)", has been launched. This strategy was, first of all, aimed at introducing information technologies into the activities of government agencies to provide state electronic services.

For these purposes, various state information systems have been created, including:

- The single portal for the provision of state electronic services;

- The portal of state (municipal) procurements;

- The state automated system "Management";

- The Internet site to ensure the smooth operation of Internet resources under the President of the Russian Federation and the Government of the Russian Federation;

- The information system for supporting the activities of multifunctional centers for the provision of state and municipal services for constituent entities of the Russian Federation;

- The network of certification centers and a network of public access to public services, etc. [6]

The Russian Federation program Information Society of 2011-2020" being implemented now consists of 6 subprograms:

- The quality of life of citizens and the conditions for the development of business.

- E-government and the public administration effectiveness.

- Russian market of information and telecommunication technologies.

- Basic infrastructure of the information society. 
- Security in the information society.

- Digital content and cultural heritage.

As the subprogram names shows, the priority areas of work on building a system of state electronic services in the Russian Federation include the need to switch to the provision of public services and the implementation of state functions in electronic form; transfer into electronic form of government accounting activities, involvement into activity of information technology and engineering components of the system of state electronic services, etc.

It is clear that all regions of the Russian Federation differ by their level of socio-economic development, as well as by the level of development in the field of information and communication technologies. Undoubtedly, this can also affect the low growth rates of the regional economic system and can be observed in the "digital inequality" in the use of information and communication technologies in certain territories.

There are many problems in organizing broadband Internet access for end users, as well as the high cost of information technology services. All this is aggravated by a high dependence on foreign products in the field of information and communication technologies and a low level of legal protection of intellectual property and personal data. [2, 9, 11]

The level of development of electronic public services for individuals in Russia with the exception of libraries (100\% security here) ranges from $25 \%$ to $50 \%$ and on average in the Russian Federation its value is equal to $42 \%$; for legal entities it is slightly higher - about $60 \%$.

It should be noted that even within these development limits, the system of information and communication technologies has already changed the nature and characteristics of the interaction between the state, business and society. If the last two decades of the last century, the state structures in our country were characterized by increasing complexity of management and controlling forms (due to the growing up of parameters and diversification of state and political institutions structure), then the involvement of modern information and communication technologies has allowed the vector of development to redirect in the opposite one. [7, 15, 17]

It should also be noted that modern information and communication technologies not only strengthened the interconnectedness of all political and economic factors, raised their awareness, but allowed at the same time to create new opportunities and new forms of opportunism. $[10,12,16]$. Involvement of state electronic services in the republics of the North-Caucasian Federal District today has already reduced territorial inequality through the established opportunities for remote contact, increasing the speed of service delivery through access to the Internet and reducing the time for processing information, increased the transparency level for the activities of state and municipal authorities due to free access to information, and also improved feedback system, etc.

At the same time, along with new opportunities for the development, information and communication technologists also constitute some serious threats that we must learn to neutralize. This, in particular, is the risk of unauthorized access to personal data, privacy, commercial secrets of recipients of such services; the risk of misappropriation of other people's property and personal non-property rights by entering a system of information and communication technologies under a false name; risk of electronic fraud; risk of destruction or distortion of information, etc.

\section{Conclusions and Proposals}

In the analysis of the awareness of representatives from various business sectors in the North Caucasus republics, it was found that more than $90 \%$ of respondents know little about 
the program "Digital Economy in Russia" and almost no one uses standardization documents in the field of digital economy in their professional activity.

In connection with this situation, we propose to create departments (groups) on the promotion and practical implementation of digital standards in the depressed North Caucasus republics with regional Ministries of Industry. In our opinion, this will mobilize all the efforts of state agencies, business organizations and civil society on the qualitative transition to a digital format for the most important standards of the digital economy, as well as make the system standard available to consumers. The study also argued that the proper involvement of the state electronic services system in parallel with the reduction of generally accepted transaction costs creates new types of costs, which must be taken into account when planning this process. (They, in particular, are the costs of identifying users, interpreting information, etc.)

The stages are analyzed and the features of the development of the information society in the Russian Federation and the world are shown, the positive and negative aspects of the informatization process and its impact on the development of the information community are considered.

Increasing the depth of use of the state electronic services system transforms the rules of relations between government agencies, the population and organizations created by them.

These changes consist in the fact that citizens and institutions have access to information about government agencies and their specific representatives, that is certainly mitigates the problem of information asymmetry, and increases the possibility of direct public control over the activities at all levels.

\section{REFERENCES}

[1] Anokhin M.G., Komarovsky V.V. Policy: the opportunities of modern technologies. - M.: RACS, 1998 , p. 70.

[2] Banasikovska Ya. The main advantages, costs and risks of the electronic form of public services // Economic sciences. 2014. No. 5, pp. 77-82.

[3] Bakhmetyev A.V. Social factors in the formation of the information society. M.: ISPI, 2013, p. 272.

[4] Gerasimov V.O., Sharafutdinov R.I., Kolmakov V.V., Erzinkyan E.A., Adamenko A.A., Vasileva A.G. Control in the human capital management system in the strategy of innovative development of a region. Entrepreneurship and Sustainability lssues. 2019. T. 7. № 2, pp.1074-1088.

[5] Drozhzhinov V., Shtrik A. Electronic government of the information society // PCWeeK. 2000. No. 15, pp. 34-39.

[6] A single portal for the provision of services http: //www.gosuslugi.com/pgu/cat/STATE_STRUCTURE. html

[7] Castells M. The Information Age: Economics, Society, Culture. M.: HSE, 2000, p. 606.

[8] Kolupaev A.A., Voronkova O.Yu., Vakhrushev I.B., Adamenko A.A., Solodkin V.S., Alekhina N.A. Corporate identity of lodging establishment as a factor of increasing tourism activity in the region. Proceedings of the $33^{\text {rd }}$ International Business Information Management Association Conference, IBIMA, 2019: Education Excellence and Innovation Management through Vision 2020, pp. 7948-7956.

[9] Kulik A.I. The electronic state in "sovereign democracy" // Materials of the X All-Russian SPC "Internet and modern society". St. Petersburg, 2007.

[10] Lomakin M.I., Dokukin A.V. Functions of a single information system for technical regulation within the framework of the e-government concept // Prospects for science. 2011. No. 7, pp. 68-76.

[11] Pavroz A.V. E-government and modern administrative reforms // Political science. 2008. No. 2, p. 167.

[12] Lee S.M., Tun X., Trini S. Current practices of Leading e-government countries // Communications of the ACM. Vol.48. Iss.10. October. 2005.

[13] Misakov V.S., Misakov A.V., Tsurova L.A., Adzhieva A.Yu., Eskiev M.A. Ways of improving the economic mechanism for the social development of rural settlements of mountainous areas//International Journal of Advanced Biotechnology and Research. 2017. V. 8. № 4, pp. 964-972.

[14] Misakov V.S., Tsurova L.A., Yandarbieva L.A., Thamadokova I. Kh., Goigova M.G. Certification of regional economic complex as a highly effective tool for analysis and diagnostics of its development // Amazonia Investiga. 2019. V. 8. № 20, pp. 451-458. 
[15] Misakov V.S., Khamzatov V.A., Temrokova A.Kh., Misakov A.V., Dikareva I.A. Strategic management of innovative agro-industrial projects // Amazonia Investiga. 2018. V. 7. № 14, pp. 16-23.

[16] Ugurchiev O.B., Dovtaev S.A.Sh., Misakov V.S., Misakov A.V., Temmoeva Z.I., Gyatov A.V. Transition mechanism development to the sustainable balanced development of depressive territories // The Turkish Online Journal of Design Art and Communication. 2018. V.8. № S-MRCHSPCL, pp. 248253.

\section{Article history:}

Received 26 February 2020

Accepted 15 May 2020 